\author{
BARbara SAwANIEWSKa, DANuTA GaJewska, Ewa LANGE
}

Katedra Dietetyki

Wydział Nauk o Żywieniu Człowieka i Konsumpcji

Szkoła Główna Gospodarstwa Wiejskiego w Warszawie

Nowoursynowska 159C, 02-776 Warszawa

E-mail: barbarasawan@gmail.com

\title{
WPŁYW SPOSOBU ŻYWIENIA NA PŁODNOŚĆ KOBIET I MĘŻCZYZN
}

\section{WPROWADZENIE}

Światowa Organizacja Zdrowia (ang. World Health Organization, WHO) definiuje niepłodność (łac. sterilitas) jako niemożność zajścia w ciążę w okresie dwóch lat, pomimo regularnego współżycia płciowego partnerów, bez stosowania jakiejkolwiek antykoncepcji (WHO 2001). Problem niepłodności dotyczy 48,5 mln par w skali globalnej, a częstość występowania i etiologia niepłodności sa zróżnicowane w poszczególnych krajach (AGARWAL i współaut. 2015). W krajach rozwiniętych częstość występowania tego zaburzenia jest mniejsza, natomiast $\mathrm{w}$ krajach rozwijających się, w których środki na badania, prewencję i leczenie sa ograniczone, skala zjawiska jest większa (WHo 2010). Polskie Towarzystwo Ginekologiczne podaje, że w Polsce problem niepłodności dotyczy 1,5 mln par (RAPORT 2015). Depresja, poczucie winy, smutek czy wstyd doświadczane przez niepłodne pary prowadza niejednokrotnie do izolacji społecznej i rozpadu związku. Wobec powagi problemu, WHO uznało niepłodność za chorobę społeczna, a leczenie zaburzeń płodności zakwalifikowano do podstawowych praw człowieka (WHO 2010).

Niepłodność kobiet pod względem klinicznym najczęściej powiazana jest $z$ zaburzeniem sekrecji hormonów płciowych (głównie zaburzenia owulacji), powikłaniami zwiazzanymi $z$ funkcjonowaniem jajników (np. zespół policystycznych jajników, PCOS), jajowodów (endometrioza) oraz macicy (np. polipy endometrialne, endometrioza w ścianie macicy).

Jeszcze do połowy XX w. wina za bezdzietność obarczano głównie kobiety. O pro- blemie męskiej niepłodności zaczęto mówić otwarcie po II wojnie światowej, natomiast dopiero w 1980 r. WHO wprowadziło normy jakości nasienia (WHO 1980). Najwyższy wskaźnik niepłodności zwiazanej z tzw. czynnikiem męskim (8-12\%) stwierdza się $\mathrm{W}$ Europie Środkowej i Wschodniej (ARGWAL i współaut. 2015).

Uważa się, że główną przyczynę niepłodności męskiej stanowia zmiany w parametrach jakości nasienia spowodowane przez stres oksydacyjny. Czynniki środowiskowe i fizjologiczne moga sprzyjać nadmiernej produkcji reaktywnych form tlenu (RFT), wpływajacc tym samym na jakość nasienia. W swietle aktualnych badań naukowych modyfikacja stylu życia może mieć istotny wpływ na wszystkie parametry zwiazane $\mathrm{z}$ ocena jakości nasienia (BRAGA i współaut. 2012). Wzrasta też świadomość osób starających się o potomstwo, że styl życia, w tym dieta sa czynnikami modyfikowalnymi, które moga mieć wpływ na płodność.

W przypadku braku możliwości zdiagnozowania przyczyny mówi się o niepłodności o nieznanej etiologii lub idiopatycznej. Szacuje się, że dotyka ona około $10-20 \%$ par (KURZAWA i współaut. 2010).

\section{STRES OKSYDACYJNY A NIEPŁODNOŚC KOBIET I MEŻCZYZN}

Reaktywne formy tlenu (RFT) sa ubocznymi produktami fosforylacji oksydacyjnej zachodzącej $\mathrm{w}$ mitochondriach. Zwiazki te uszkadzaja białka, lipidy i czasteczki DNA. Powoduja zaburzenia ich funkcji biologicznej

Słowa kluczowe: dieta, dieta śródziemnomorska, dieta typu zachodniego, jakość parametrów nasienia, płodność, stres oksydacyjny 
poprzez nieodwracalna modyfikację struktury (HuANG i MANTON 2004). Niskie, tzw. fizjologiczne poziomy RFT w nasieniu, których produkcja znajduje się pod stała kontrola występujacych tam systemów antyoksydacyjnych, odgrywaja istotna rolę $\mathrm{w}$ prawidłowej czynności plemników. Reaktywne formy tlenu biora udział w kluczowych procesach prowadzacych do zapłodnienia, takich jak: kapacytacja, hiperaktywacja, reakcja akrosomalna plemnika i fuzja plemnika $z$ oocytem. Zaburzenie istniejącej równowagi oksydo-redukcyjnej skutkuje wystapieniem stresu oksydacyjnego (WALCZAK-JĘDRZEJOWSKA 2015a, b). Badania dowodzą, że RFT moga znacząco wpływać na jakość nasienia i funkcje rozrodcze mężczyzn, których niepłodność jest w 30-80\% przypadków wynikiem działania RFT w nasieniu (AGARWAL i współaut. 2007). Szczególnie wrażliwa na ich działanie jest błona komórkowa plemników, ponieważ zawiera duże ilości nienasyconych kwasów tłuszczowych, które $z$ łatwościa ulegaja procesowi utleniania (KEMAL i współaut. 2000).

Głównym źródłem RFT w nasieniu sa leukocyty i same plemniki (SALEH i AGRWAL 2002). Zdolność generowania wolnych rodników przez plemniki jest zależna od stadium ich dojrzałości (SAID i współaut. 2005). W warunkach fizjologicznych leukocyty wytwarzaja nawet do 1000 razy więcej RFT niż plemniki. Tak wysoka produkcja RFT przez leukocyty odgrywa istotna rolę $\mathrm{w}$ mechanizmie obrony komórkowej w zakażeniach i stanach zapalnych. Wzrost liczby leukocytów $\mathrm{w}$ nasieniu może być także wynikiem działania szkodliwych czynników środowiskowych, długiej abstynencji seksualnej czy stanów patologicznych układu rozrodczego (np. żylaków powrózków nasiennych) (MARTINEZ i współaut. 2007). Z kolei GUZ i współaut. (2013) nie znaleźli związku między parametrami stresu oksydacyjnego $\mathrm{w}$ nasieniu niepłodnych mężczyzn a parametrami stresu oksydacyjnego (tzn. ogólnoustrojowego) w leukocytach krwi obwodowej.

Układ zapewniający równowage oksydo-redukcyjna $\mathrm{w}$ nasieniu składa się $\mathrm{z}$ czynników enzymatycznych i nieenzymatycznych, które wspólnie zapewniaja optymalna ochronę przed nadmierna produkcja RFT. Ich udział jest o tyle istotny, że w przypadku niedoboru któregokolwiek $\mathrm{z}$ nich może dojść do obniżenia całkowitego potencjału antyoksydacyjnego. Triada enzymatyczna, w skład której wchodzi dysmutaza ponadtlenkowa, katalaza i peroksydaza glutationowa, pełni podstawowa rolę $\mathrm{w}$ układzie antyoksydacyjnym. Aktywność enzymów wspomagaja niskoczasteczkowe, nieenzymatyczne antyoksydanty. Należą do nich między innymi: glutation, kwas pantotenowy, witamina A, E i
C oraz witaminy $z$ grupy $B$, cynk, miedź $i$ selen. Niedobór tych składników może wpływać na nieprawidłowa aktywność enzymów, a w konsekwencji na obniżenie jakości nasienia (AGARWAL i współaut. 2007).

Także u kobiet reaktywne formy tlenu w niewielkich stężeniach sa niezbędne do prawidłowego funkcjonowania układu rozrodczego. Reaktywne formy tlenu jako cząsteczki sygnałowe maja wpływ na wiele procesów fizjologicznych, w tym na zachowanie cykliczności menstruacji i apoptozę oocytów. Moga też regulować dojrzewanie oocytu, odgrywaja istotna rolę $\mathrm{w}$ folikulogenezie czy luteolizie (GUÉRIN i współaut. 2001). Mitochondria sa centrum metabolicznym komórki, a wszelkie zaburzenia $\mathrm{w}$ ich funkcjonowaniu moga powodować redukcję stężenia adenozynotrifosforanu (ATP), co wplywa także na procesy metaboliczne w oocytach. Zaburzenie równowagi prooksydacyjno-antyoksydacyjnej organizmu może także powodować niepłodność o niezidentyfikowanej etiologii. Stres oksydacyjny u kobiet może być przyczyna niepłodności idiopatycznej, a także może być powiazany $z$ występowaniem zespołu policystycznych jajników, a w czasie ciąży zwiększać ryzyko wystapienia stanu przedrzucawkowego, spontanicznych poronień czy wewnątrzmacicznego zahamowania wzrostu płodu (AGARWAL i współaut. 2012). Podwyższone stężenie RFT oraz produktów peroksydacji lipidów, a także znacznie obniżona aktywność dysmutazy ponadtlenkowej stwierdzono u kobiet ze zdiagnozowana endometrioza (LIU i współaut. 2001).

\section{WPŁYW SPOSOBU ŻYWIENIA NA PEODNOŚC}

W ostatniej dekadzie znacznie wzrosło zainteresowanie wplywem sposobu żywienia na płodność zarówno mężczyzn, jak i kobiet. Wykazano zależności między wzorcami żywienia a jakościa parametrów nasienia (ESLAMIN i współaut. 2016, KARAYIANNIS i współaut. 2017, JUREWICZ i współaut. 2018, RICCI i współaut. 2018), stężeniem hormonów płciowych, objętością gonad męskich jako markerów ich funkcji (CUTILLAS-TOLINI i współaut. 2015), występowaniem owulacji oraz osiagnięciem sukcesu reprodukcyjnego po zapłodnieniu pozaustrojowym (ang. in vitro fertilisation, IVF/ ang. interacytoplasmic sperm injection, ICSI) (VUJKOVIC i współaut. 2009, TOLEDO i współaut. 2011, KARAYIANNIS i współaut. 2018).

Dieta śródziemnomorska charakteryzuje się wysokim udziałem warzyw i owoców, roślin straczkowych, pełnoziarnistych produktów zbożowych, orzechów, oliwy $z$ oliwek, ryb i owoców morza oraz niskim udziałem czer- 
wonego mięsa (GARCÍA-FERNÁNDEZ i współaut. 2014). Z kolei sposób żywienia „prudent pattern" określany jako racjonalny, charakteryzuje się zgodnością $z$ zasadami prawidłowego żywienia i włączeniem do jadłospisu m.in. zielonych warzyw liściastych, żółtych warzyw i pomidorów oraz innych warzyw, ryb i owoców morza, owoców i naturalnych soków owocowych, roślin straczkkowych, pełnoziarnistych produktów zbożowych, drobiu, herbaty i kawy, niskotłuszczowych produktów mlecznych i olejów roślinnych (GASKINS i współaut. 2012).

Dieta śródziemnomorska oraz dieta „prudent pattern", charakteryzuja się wysokim udziałem warzyw i owoców, które sa źródłem węglowodanów złożonych, błonnika i białka pochodzenia roślinnego. Każdy $z$ tych składników pełni istotne funkcje w organizmie, ważne także dla zachowania „zdrowia prokreacyjnego". Wśród najcenniejszych warzyw bogatych w $\beta$-karoten, witaminę $C, E$, $\mathrm{B}_{6}$ oraz kwas foliowy, potas, żelazo i magnez należy wymienić: paprykę, pomidory, buraki, dynię, ciemnozielone warzywa liściaste, takie jak: szpinak, rukola, roszponka, oraz warzywa kapustne m.in.: brokuł, kalafior, jarmuż, brukselka, kapusta głowiasta biała i czerwona. Szczególnie cenne, ze względu na właściwości przeciwutleniające, sa owoce jagodowe, w tym: agrest, acerola, aronia, borówka, czarne jagody, jeżyny, maliny, truskawki, poziomki, winogrona i żurawina (JAROSZ 2017).

Dieta typu zachodniego charakteryzuje się wysokim udziałem przetworzonego i nieprzetworzonego czerwonego mięsa, dań typu „fast food", wysokoprzetworzonej żywności, pełnotłustego nabiału, słodkich produktów piekarniczych, ziemniaków, jajek, gotowych sosów, słodyczy i słodkich napojów (TOLEDO i współaut. 2011). Taki model żywienia, obok wysokiego udziału nasyconych kwasów tłuszczowych oraz łatwo przyswajalnych węglowodanów i cukrów dodanych, charakteryzuje się wysokim udziałem żywności zawierającej wielonienasycone kwasy tłuszczowe o konfiguracji trans. Do podstawowych źródeł w diecie tych niekorzystnych dla zdrowia kwasów tłuszczowych należą produkty zawierajace przemysłowo utwardzone oleje roślinne, pieczywo, potrawy smażone, chipsy, żywność typu „fast food", tłuszcze piekarnicze, ciasteczka, krakersy, wyroby cukiernicze, lody i wyroby czekoladowe (MOJSKA 2006, Cichosz i CzECZOT 2012).

Wyniki analiz DANIELEWICZ i współaut. (2018) oraz GASKINS i współaut. (2012) jako jedne $z$ nielicznych pozostaja w sprzeczności z rosnąca liczbą badań wskazujących na pozytywny związek między spożyciem tzw. „zdrowej” żywności a parametrami jakości nasienia. Potwierdza to konieczność przeprowadzenia dobrze zaprojektowanych randomizowanych i interwencyjnych badań, które moga przyczynić się do opracowania skutecznych programów profilaktycznych i interwencyjnych dla par starajacych się o dziecko.

\section{WPŁYW MAKROSKŁADNIKÓW POKARMOWYCH NA PŁODNOŚĆ KOBIET I MEZZCZYZN}

\section{BIAŁKO}

Białko jest podstawowym strukturalnym i funkcjonalnym składnikiem każdej komórki, a zatem jego obecność w diecie jest niezbędna dla prawidłowego funkcjonowania organizmu, w tym również układu rozrodczego u obu płci. CHAVARRo i współaut. (2008) wykazali, że dostarczenie $5 \%$ energii pochodzącej $z$ białka roślinnego zamiast energii pochodzącej $z$ białka zwierzęcego, zmniejszało ryzyko względne wystapienia niepłodności o co najmniej 50\%. Podobnie, zastapienie 5\% energii pochodzacej $z$ białka roślinnego zamiast energii pochodzaccej $z$ węglowodanów, wiazało się ze zmniejszeniem ryzyka niepłodności o 43\% u kobiet powyżej 32 roku życia. Odwrotna zależność odnotowano w przypadku spożycia białka zwierzęcego; zastapienie $5 \%$ energii pochodzacej $z$ tego składnika w miejsce węlowodanów było związane z 19\% wzrostem ryzyka wystapienia niepłodności. Ponadto, zwiększenie spożycia białka przez badane osoby o dodatkowa porcję mięsa dziennie (przede wszystkim kurczaka, indyka i w mniejszym stopniu czerwonego mięsa), przy zachowaniu takiej samej energetyczności racji pokarmowej, wiązało się ze wzrostem ryzyka niepłodności o 32\%. Prawdopodobnie efekt ten jest zwiazany $z$ korzystnym wpływem białka pochodzenia roślinnego na wrażliwość komórek na insulinę. Przypuszcza się, że pewne znaczenie może mieć także obniżenie stężenia insulinopodobnego czynnika wzrostu (ang. insulin-like growth factor, IGF-1) we krwi, zwiazane ze spożyciem tego rodzaju białka. Hormon ten wydaje się odgrywać istotna rolę w patogenezie zespołu policystycznych jajników, który często wiąże się $z$ zaburzeniami owulacji. Ponadto, arginina występujaca $\mathrm{w}$ białku roślinnym, jest substratem do produkcji tlenku azotu, który ma działanie wazodylatacyjne, a więc poprawia przepływ krwi przez narzad rodny, sprzyjając oogenezie, a także implantacji (SzOSTAK-WEGIEREK 2011). Szczególnie bogate $\mathrm{w}$ argininę sa pestki dyni, słonecznika, siemię lniane, migdały, orzechy włoskie, sezam oraz rośliny straczkowe: soja, soczewica i groch (KUNACHOWICZ i współaut. 2017). 
Najwięcej białka spośród wszystkich roślin uprawnych zawieraja nasiona roślin strączkowych, do których należą: fasola, groch, bób, soja, soczewica i ciecierzyca. W zależności od gatunku i warunków uprawy zawartość białka waha się od 20\% (groch, fasola) do $42 \%$ (soja), a jego wartość biologiczna jest wyższa od białka zbóż. Nasiona roślin strączkowych wyróżniaja się wyższym udziałem lizyny (zwłaszcza groch) i treoniny, natomiast czynnikiem ograniczajacym jego wartość biologiczna jest niedostateczna zawartość aminokwasów siarkowych (metioniny i cystyny) oraz tryptofanu. Spośród pokarmów roślinnych najkorzystniejszy skład aminokwasowy ma białko soi. Ponadto, nasiona roślin strączkowych zawieraja duże ilości potasu, żelaza, miedzi i cynku, witamin $z$ grupy $B$ (tiamina, ryboflawina, witamina PP) oraz witaminę E (KAPUSTA 2012).

\section{TŁUSZCZE}

Ważnym składnikiem pokarmowym wpływajacym korzystnie lub niekorzystnie na płodność jest ilość i jakość tłuszczu w diecie. Znaczacym źródłem tłuszczu pokarmowego sa oleje roślinne, mleko i przetwory mleczne, mięso i jego przetwory, ryby, jaja, orzechy i nasiona roślin oleistych oraz produkty cukiernicze. Nadmierna konsumpcja wysoko przetworzonej żywności, mięsa oraz wyrobów mięsnych może prowadzić do znacznego wzrostu spożycia tłuszczu ogółem, a w nim nasyconych kwasów tłuszczowych, które w nadmiarze moga wpływać na obniżenie płodności. W badaniu JENSEN i współaut. (2013) analizowano związek pomiędzy spożyciem tłuszczów a jakościa parametrów nasienia. Mężczyźni, którzy spożywali nasycone kwasy thuszczowe na poziomie co najmniej 15,2\% wartości energetycznej ich zwyczajowej diety charakteryzowali się gorszymi parametrami nasienia, w tym niższą o $38 \%$ koncentracja plemników oraz niższą o $41 \%$ całkowita ich liczba, w porównaniu do mężczyzn spożywających te kwasy tłuszczowe poniżej 11,2\% wartości energetycznej diety. Szkodliwy wpływ nadmiernego spożywania tłuszczu (całkowitego i nasyconych kwasów tłuszczowych) na liczbę i koncentracje plemników zidentyfikowano również $\mathrm{w}$ badaniu ATTMAN i współaut. (2012). Mężczyźni, którzy spożywali nadmierna ilość tłuszczu (tj. od 34 do $44 \%$ energii $z$ diety) mieli o $43 \%$ niższa całkowita liczbe plemników i o $38 \%$ niższa liczebność plemników w jednostce objętości nasienia, w porównaniu $z$ mężczyznami spożywającymi od 19 do $29 \%$ thuszczu w diecie. Wykazano również, że wysokie spożycie nasyconych kwasów tłuszczowych $(13 \%$ energii $z$ diety) obniżało liczbę plemników, podczas gdy wyższe spożycie kwasów tłuszczowych z rodziny omega-3 miało korzystny wpływ na morfologie tych gamet.

Badania wykazuja, że u zdrowych mężczyzn spożycie nienasyconych kwasów tłuszczowych o konfiguracji trans było odwrotnie proporcjonalne do całkowitej liczby plemników, a spożycie cholesterolu - do objętości ejakulatu (CHAVARRO i współaut. 2014). Również u kobiet, żywność będąca źródłem kwasów tłuszczowych o konfiguracji trans ma zwiazek $\mathrm{z}$ płodnościa. CHAVARRO i współaut. (2007) udokumentowali dwukrotny wzrost ryzyka wystapienia niepłodności, gdy $2 \%$ energii pochodzacej $z$ jednonienasyconych kwasów tłuszczowych (MUFA) zastapiono energia pochodzaca $z$ kwasów tłuszczowych o konfiguracji trans. Spożywanie tłuszczów o konfiguracji trans zwiększyło o $73 \%$ ryzyko wystapienia zaburzeń owulacji. Wykazano również, że zwiększenie spożycia energii $z$ nienasyconych kwasów tłuszczowych o konfiguracji trans (o 2\%), kosztem węglowodanów oraz wielonienasyconych kwasów tłuszczowych (PUFA) i jednonienasyconych kwasów tłuszczowych (MUFA) powiąane było ze wzrostem ryzyka wystapienia niepłodności z powodu zaburzeń owulacji o odpowiednio $73 \%, 79 \%$ i 131\%. Wyjaśnienia tego zjawiska poszukuje się w działaniu kwasów tłuszczowych o konfiguracji trans na aktywność receptorów aktywowanych przez proliferatory peroksysomów (PPAR- $\gamma$ ) (ang. peroxisome proliferator-actived receptor). W badaniu SARAVANAN i współaut. (2005) stwierdzono, że na poziomie zwyczajowego spożycia kwasów tłuszczowych o konfiguracji trans, moga one obniżać ekspresję PPAR- $\gamma$ o około $40 \%$ Rola PPAR- $\gamma$ polega $m . i n$. na regulowaniu homeostazy glukozy i kwasów tłuszczowych oraz zmniejszaniu ilości tkanki tłuszczowej $\mathrm{w}$ organizmie, a przez to przeciwdziałaniu otyłości, hiperlipidemii i oporności na insulinę Badania prowadzone w programie Nurses' Health Study II (NHS II) wykazały, że spożycie kwasów thuszczowych o konfiguracji trans może przyczyniać się do rozwoju otyłości (zwłaszcza trzewnej), zmniejszenia insulinowrażliwości i powstania insulinooporności oraz rozwoju cukrzycy typu 2 (CHAVARRO i współaut. 2007).

Spożywanie przez kobiety dużych ilości tłuszczu może wpływać na zdolność komórek jajowych do zapłodnienia. Wyniki badań przeprowadzonych przez KAZEMII i współaut. (2014) wykazały, że wyższy poziom spożycia tłuszczu był dodatnio skorelowany $z$ liczba pobranych oocytów i odwrotnie zwiąany $z$ jakościa zarodków wykorzystywanych $\mathrm{w}$ technice wspomaganego rozrodu. Wyższa jakość oocytów odnotowano u kobiet, których dieta zawierała mniej niż 35\% energii pochodzacej $\mathrm{z}$ thuszczu. 
Badania na modelach zwierzęcych wskazują, że wysokie spożycie tłuszczu negatywnie wpływa zarówno na rozwój pęcherzyków jajnikowych, jak i zdolność oocytów do zapłodnienia (FOULADI-NASHTA i współaut. 2007, PETIT i współaut. 2008).

W badaniu MENDIOLA i współaut. (2009) dotyczącym wpływu żywności na jakość nasienia mężczyzn stwierdzono, że wyższe spożycie przetworzonych produktów mięsnych (np. kiełbasy, wędliny) o wysokiej zawartości nasyconych kwasów tłuszczowych miało związek $z$ niższą jakością nasienia. U mężczyzn, którzy częściej spożywali odtłuszczone mleko i mniejsze ilości produktów mlecznych, a w konsekwencji mniej produktów będących źródłem substancji lipofilnych, takich jak ksenoestrogeny, jakość nasienia była wyższa. Ponadto, mężczyźni ci spożywali więcej warzyw i owoców, a tym samym więcej przeciwutleniaczy i mikroelementów korzystnie wpływających na jakość plemników.

Ksenoestrogeny sa substancjami wysoce lipofilnymi, które moga gromadzić się w pokarmach o wysokiej zawartości tłuszczu (czerwone mięso, mleko i produkty mleczne). Należą do nich między innymi polichlorowane bifenyle, zwiazki chloroorganiczne występujace $\mathrm{w}$ pestycydach, i estry ftalanowe. Ksenoestrogeny oraz steroidy anaboliczne i inne hormony moga wbudowywać się w błonę plemników i w rezultacie zmniejszać ruchliwość nasienia (RozATI i współaut. 2002). Trzeba jednak pamiętać, że ograniczenie lub wręcz unikanie spożycia czerwonego mięsa, tłuszczów i cholesterolu może zmniejszyć syntezę hormonów płciowych.

Diety o niskiej zawartości tłuszczów i nienasyconych kwasów tłuszczowych (NNKT) sa zwiazane ze skróceniem fazy lutealnej cyklu, oligomenorrhea (rzadkie miesiaczki) i przedwczesnym porodem (LANGLEY 2014). Korzystny wpływ na płodność ma spożycie jedno- i wielonienasyconych kwasów tłuszczowych, głównie pochodzenia roślinnego. Oliwa $z$ oliwek, olej rzepakowy oraz olej słonecznikowy zawieraja kwas oleinowy należacy do rodziny MUFA o konfiguracji cis. Wielonienasycone kwasy tłuszczowe, należace do rodzin omega-6 i omega-3 nie sa syntetyzowane w organizmie człowieka, $z$ tego względu kwas linolowy i a-linolenowy, prekursory długołańcuchowych wielonienasyconych kwasów tłuszczowych $z$ rodzin odpowiednio omega-6 i omega-3, muszą być dostarczane $z$ dieta. Niezbędne nienasycone kwasy tłuszczowe (m.in. kwas linolowy) sa prekursorami prostaglandyn, istotnych dla zainicjowania cyklu miesiączkowego, wzrostu i rozwoju pęcherzyków jajnikowych i owulacji. Prostaglandyny biorą udział w utrzymaniu ciaży przez przygotowanie endometrium macicy do zagnieżdżenia zarodka i utrzymania ciąży. Może to oznaczać, że wyższe spożycie kwasu linolowego korzystnie wpływa na implantację zapłodnionej komórki jajowej (ACHACHE i REVEL 2006). Kwas linolowy występuje powszechnie w olejach roślinnych, m.in. olej $z$ pestek winogron zawiera go od 58 do $78 \%$, sojowy od 48 do $59 \%$, szafranowy od 68 do $83 \%$, a rzepakowy od 15 do $30 \%$ (JAROsZ 2017).

Poziom oraz wzajemne proporcje niezbędnych nienasyconych kwasów tłuszczowych w diecie wpływaja również na płodność mężczyzn. Wykazano, że stężenie kwasów tłuszczowych omega-3 w osoczu krwi i w plemnikach płodnych mężczyzn było wyższe niż w grupie mężczyzn niepłodnych. Stosunek stężenia kwasów tłuszczowych omega-6 do omega -3 w osoczu był znacznie wyższy u mężczyzn niepłodnych, w porównaniu $z$ grupą kontrolna płodnych mężczyzn. Zwiększony udział kwasów tłuszczowych omega-6 w diecie wiązał się ze zmniejszeniem koncentracji plemników w nasieniu, ich ruchliwości i zmianami w ich morfologii, co sugerowało potencjalne przyczyny zmniejszonej płodności.

W badaniu SAFARIENJADA (2010) suplementacja kwasami tłuszczowymi omega-3 diety mężczyzn $z$ oligoastenoteratospermia (obniżona całkowita liczba, ruchliwość i morfologia plemników) wpłynęła na poprawe parametrów jakości nasienia. Po 32 tygodniach tej interwencji żywieniowej w grupie badanej stwierdzono istotny wzrost całkowitej liczby plemników, ich koncentracji w jednostce objętości nasienia, w porównaniu do grupy kontrolnej. Stwierdzono również zwiększona aktywność antyoksydacyjna osocza nasienia.

\section{WĘGLOWODANY}

Podstawę prawidłowo zbilansowanej diety powinny stanowić węglowodany, które sa substratem energetycznym w procesach utleniania komórkowego. CHAVARRO i współaut. (2009) wykazali, że ilość i jakość spożywanych węglowodanów wpływa na występowanie zaburzeń owulacji. Stwierdzono, że wysokie spożycie łatwo przyswajalnych węlowodanów i wysoki indeks glikemiczny diety były częściej związane ze zwiększeniem ryzyka niepłodności spowodowanej brakiem owulacji.

U mężczyzn częste spożywanie żywności przetworzonej, a tym samym łatwo przyswajalnych węglowodanów prostych, prowadzi do wzrostu glikemii i rozwoju insulinooporności, co może powodować wzrost stresu oksydacyjnego (PARK i współaut. 2009), negatywnie wpływającego także na jakość nasienia (Mendiola i współaut. 2010). Działanie osi 
podwzgórze-przysadka-gonady, odpowiedzialnej za regulację spermatogenezy, może zostać zakłócone przez wysokie stężenia glukozy i insuliny (SCHOELLER i współaut. 2012).

\section{WPEYW WYBRANYCH MIKROSKŁADNIKÓW POKARMOWYCH NA PŁODNOSC KOBIET I ME¿ZCZYZN}

Istotne znaczenie dla zachowania prawidłowych funkcji układu rozrodczego kobiet i mężczyzn maja także witaminy i składniki mineralne. Planujac dietę wspomagajaca płodność szczególna uwage należy zwrócić na obecność witamin $\mathrm{z}$ grupy $\mathrm{B}$, ponieważ kwas foliowy $i$ witamina $B_{6}$, razem $z$ witamina $B_{12}$, biora udział $\mathrm{w}$ procesie metylacji DNA i zapobiegaja nadmiernemu powstawaniu homocysteiny (HAJDUK 2013). Duże stężenie tego aminokwasu w płynie pęcherzyków Graafa prowadzi do nieprawidłowego połączenia plemnika $z$ oocytem, co sprawia, że prawdopodobieństwo poczęcia dziecka znacznie maleje (BUHLING i GRAJECKI 2013).

Witamina $\mathrm{B}_{6}$ jest koenzymem zaangażowanym $\mathrm{w}$ wiele szlaków przemian biochemicznych. Uczestniczy $\mathrm{w}$ metabolizmie tłuszczów oraz moduluje działanie hormonów steroidowych nadnerczowych $i$ gonadowych (OKA 2001). Produkty spożywcze bogate w witaminę $\mathrm{B}_{6}$ to głównie: ryby (łosoś, makrela, pstrag tęczowy), mięso (drobiowe, wieprzowe), ale także rośliny strączkowe, orzechy i nasiona. Dobrym źródłem tej witaminy sa również czosnek, curry, imbir, chili, pełnoziarniste produkty zbożowe, brązowy ryż, komosa ryżowa czy kiełki pszenicy. Spośród owoców i warzyw, które zawieraja istotne ilości witaminy $\mathrm{B}_{6}$ należy wymienić: banany, morele suszone, paprykę czerwona, pomidory, kapustę kwaszoną i ziemniaki (JAROSZ 2017).

Nieodpowiednia podaż witaminy $\mathrm{B}_{12} \mathrm{~W}$ diecie kobiet skutkuje zahamowaniem owulacji oraz niewłaściwa implantacja zarodka, natomiast u mężczyzn znacznym obniżeniem ruchliwości plemników (SHUKLA i SARIKA 2014). Źródłem kobalaminy (witaminy $\mathrm{B}_{12}$ ) są wyłącznie produkty zwierzęce: mięso, ryby, mleko i produkty mleczne oraz jaja. Osoby wykluczajace ze swojej diety produkty pochodzenia zwierzęcego musza stosować suplementację witaminy B12 (JAROSZ 2017).

Niedokrwistość $z$ powodu niedoboru żelaza związana jest $z$ ryzykiem przedwczesnego porodu oraz niska masa urodzeniowa dziecka. Odpowiednia podaż żelaza przed i $\mathrm{w}$ czasie ciąży zmniejsza ryzyko wad cewy nerwowej u płodu (HAJDUK 2013). W produktach spożywczych występuja dwa rodzaje żelaza: hemowe (w produktach pochodzenia zwierzęcego) i niehemowe ( $\mathrm{w}$ produktach ro- ślinnych). Brak czerwonego mięsa $\mathrm{w}$ diecie, które jest źródłem żelaza hemowego może być związane $z$ większym ryzykiem wystapieniem niedokrwistości, brakiem miesiączki i zaburzeniami łaknienia (LANGLEY 2014). Dużą ilość żelaza dostarczają czerwone mięso i jaja, a także natka pietruszki oraz suche nasiona roślin straczkowych (JAROSZ 2017).

Obok warzyw i owoców bogatym źródłem antyoksydantów w diecie, $w$ tym selenu $\mathrm{i}$ cynku, sa orzechy, nasiona i pestki. Selen chroni DNA plemników przed działaniem RFT. Jest on składnikiem uczestniczacym $\mathrm{w}$ przebiegu spermatogenezy oraz wpływa na prawidłową ruchliwość plemników. Niedobór selenu $\mathrm{w}$ diecie może być przyczyna zaniku nabłonka plemnikotwórczego, zaburzeń spermatogenezy oraz nieprawidłowego dojrzewania plemników w najadrzach. Morfologia plemników, zwiąana głównie $z$ nieprawidłowym rozwojem główki i wstawki, jest powiazana $z$ niedoborem selenu. Selen odgrywa również znacząca rolę $\mathrm{w}$ funkcjonowaniu układu rozrodczego kobiet. Niedobór tego składnika może prowadzić do powikłań ciąży, poronień i uszkodzenia układu nerwowego i odpornościowego płodu. Niskie stężenie selenu w surowicy krwi we wczesnym stadium ciaży jest czynnikiem predykcyjnym niskiej masy urodzeniowej noworodka. $Z$ tych powodów bardzo istotny jest odpowiedni udział selenu $\mathrm{w}$ diecie kobiet i mężczyzn w wieku prokreacyjnym (PIECZYŃSKI I GRAJETA 2014). $Z$ drugiej strony, nadmiar selenu $\mathrm{w}$ diecie, czyli selenoza, może wystapić $\mathrm{w}$ przypadku długotrwałego spożywania tego pierwiastka w ilości $400 \mu \mathrm{g}$ na dobę. Objawy świadczace o selenozie to wypadanie włosów, czosnkowy zapach $\mathrm{z}$ ust, biegunka i zaburzenia neurologiczne. Skutkiem długotrwałej nadmiernej suplementacji selenem może być cukrzyca, a także marskość watroby, obrzęk płuc, a nawet zgon (RATAJCZAK i GIETKA-CZERNEL 2016). Zródłem selenu $\mathrm{w}$ diecie sa przede wszystkim orzechy brazylijskie. Jeden orzech pokrywa dzienne zapotrzebowanie dostarczajacc $55 \mu \mathrm{g}$ selenu. Inne bogate źródła selenu to: sezam, orzechy włoskie, maka pełnoziarnista oraz płatki owsiane, a także ryby, m.in. łosoś, halibut i dorsz (JAROSZ 2017).

Cynk wchodzi w skład ponad 300 enzymów (m.in. dysmutazy ponadtlenkowej), które uczestnicza w biosyntezie kwasów nukleinowych i białek. Obecność cynku jest niezbędna do syntezy i prawidłowego funkcjonowania hormonów, w tym insuliny i tyroksyny. Wykazano, że cynk warunkuje właściwy przebieg owulacji i cyklu miesiaczkowego, ma wpływ na metabolizm estrogenów, progesteronu i androgenów. Niedobory tego 
pierwiastka mogą ograniczać rozwój płodu, zwiększać ryzyko porodów przedwczesnych, samoistnych poronień oraz wad rozwojowych płodu (EBISH i współaut. 2007). Stężenie cynku w osoczu nasienia jest wyższe niż we krwi, ponieważ pierwiastek ten uczestniczy w obronie gamet przed bakteriami i chroni chromosomy przed uszkodzeniem. Odgrywa też istotna rolę w rozwoju gonad, bierze udział $w$ procesie spermatogenezy i wpływa na ruchliwość plemników. Badania wskazuja, że niskie stężenie cynku w osoczu nasienia zwiazane jest ze spadkiem całkowitej liczby plemników, ale zwiększony poziom cynku w osoczu nasienia powoduje zmniejszenie ruchliwości plemników. Oznacza to, że podaż cynku $z$ dieta i suplementacja oraz stężenie cynku w osoczu nasienia powinny być uważnie monitorowane (KHAN i współaut. 2011). Do bogatych źródeł cynku zalicza się pieczywo razowe, sery podpuszczkowe, mięso i kaszę gryczana, a jego przyswajalność jest większa $z$ produktów zwierzęcych niż roślinnych. Wchłanianie cynku $z$ diety wynosi 20-40\%, przy czym wzrasta przy niedoborach tego składnika w organizmie (CETIN i współaut. 2010). Korzystny wpływ na przyswajalność cynku maja niektóre aminokwasy i kwas cytrynowy, a jego przyswajalność ogranicza obecność fitynianów, błonnika i szczawianów, a także niektóre składniki mineralne (np. miedź, żelazo niehemowe, wapń) oraz alkohol (CHAVARRO i współaut. 2009).

\section{MASA CIAŁA A PŁODNOŚĆ}

Otyłość stała się globalnym problemem współczesnego świata. Ostatni raport WHO informuje, że otyłość dotyczy ponad 600 milionów dorosłych na całym świecie (WHO 2017). Pewna ilość tkanki tłuszczowej u kobiet jest niezbędna do prawidłowego funkcjonowania układu rozrodczego. Jej nadmiar natomiast, prowadzac do nadwagi i otyłości, może mieć negatywny wpływ na potencjał rozrodczy, głównie $z$ powodu zaburzeń funkcjonowania osi podwzgórze-przysadka-gonady (HPG) (RACHON i TEEDE 2010). Szczególnie niebezpieczny jest nadmierny udział tkanki tłuszczowej wisceralnej, ponieważ może korelować $z$ większym ryzykiem insulinooporności, hiperinsulinemii, hiperandrogenemii oraz wzrostem obwodowej aromatyzacji androgenów do estrogenów. To prowadzi do ujemnego sprzężenia zwrotnego osi HPG, wpływa na syntezę gonadotropin i objawia się zaburzeniami miesiączkowania i owulacji. Hiperinsulinemia jest zwiazana $z$ patogeneza zespołu policystycznych jajników, charakteryzujaca się brakiem owulacji i hiperandrogenizmem (MORAN i współaut. 2015). Nad- mierna masa ciała może upośledzać sekrecję progesteronu przez ciałko żółte. Hormon ten przygotowuje błonę śluzowa macicy do przyjęcia zarodka powstałego $z$ zapłodnionej komórki jajowej i umożliwia jego rozwój. Rolę ciałka żółtego w późniejszym etapie cią̇y przejmuje łożysko (ZIOMKIEWICZ i współaut. 2008).

Nadmiar energii dostarczanej $z$ dieta powoduje, że kwasy tłuszczowe gromadza się w innych niż tkanka tłuszczowa narzadach i tkankach, wywierając działanie toksyczne, które określa się jako lipotoksyczność (SoRENSEN i współaut. 2010). Kobiety otyłe maja wyższe poziomy krążacych wolnych kwasów tłuszczowych, które uszkadzają komórki inne niż adipocyty, poprzez zwiększenie ilości wytwarzanych RFT. Te $z$ kolei indukuja stres mitochondrialny $i$ stres siateczki śródplazmatycznej, prowadzacy do apoptozy, czyli programowanej śmierci komórki (BROUGHTON i JUNGHEIM 2016). Lipotoksyczność odgrywa znacząca rolę w rozwoju insulinooporności i utrzymywaniu stanu zapalnego. Tkanka tłuszczowa jest narządem wewnątrzwydzielniczym, który wytwarza wiele adipokin prozapalnych, w tym leptynę, czynnik martwicy nowotworów a (TNF- $\alpha$ ) i interleukinę 6 (IL6) (McGown i współaut. 2014). Otyłe kobiety maja wyższe stężenie białka C-reaktywnego (CRP) we krwi, wskaźnika ogólnoustrojowego stanu zapalnego (SALAZAR i MARTINEZ 2014). Obserwuje się również podwyższone stężenie tego białka i leptyny w płynie pęcherzykowym (ROBKER i współaut. 2009).

Utrzymanie równowagi energetycznej organizmu warunkuje prawidłowe funkcjonowanie układu rozrodczego kobiet, zachowanie prawidłowych funkcji jajników i regularność cyklu menstruacyjnego (SERDYŃSKA i współaut. 2008). Niedowaga (wskaźnik masy ciała, BMI poniżej $18,5 \mathrm{~kg} / \mathrm{m}^{2}$ ) może być też związana $z$ niedostatecznym spożyciem witamin i składników mineralnych, co również stanowi ryzyko niepłodności, głównie poprzez wpływ na skrócenie fazy lutealnej, zaburzenie miesiaczkowania oraz zwiększone wydzielanie hormonu folikulotropowego (FSH) (MAKAR i TOTH 2002).

$Z$ badań wynika, że również otyli mężczyźni (z BMI powyżej $35 \mathrm{~kg} / \mathrm{m}^{2}$ ) mieli niższa całkowita liczbę plemników niż mężczyźni o prawidłowej masie ciała. Wraz ze wzrostem masy ciała mężczyzn malały także objętość ejakulatu, koncentracja plemników w nasieniu i ich ruchliwość. Wskaźnik masy ciała mężczyzn był dodatnio skorelowany $z$ poziomem 17 $\beta$-estradiolu i odwrotnie proporcjonalny do stężenia globuliny wiążacej hormony płciowe (ang. sex hormone binding globulin, SHBG). Nadmiar tkanki tłuszczowej powoduje także zwiększoną konwersję testo- 
steronu do 17-estradiolu, co może prowadzić do wtórnego hipogonadyzmu poprzez supresję osi gonadowej. Badacze sugeruja jednak, że tylko skrajne formy otyłości moga negatywnie wpływać na męski potencjał reprodukcyjny (CHAVARRO i współaut. 2010). W grupie mężczyzn otyłych częściej stwierdzano wysoki stopień uszkodzenia materiału DNA w plemnikach niż u mężczyzn o prawidłowej masie ciała. Otyłość może doprowadzić także do przegrzewania jąder $\mathrm{w}$ wyniku nagromadzenia tkanki tłuszczowej w okolicach pachwin (PALMER i BAKOS 2012).

W dużym systematycznym przegladzie obejmującym 40 badań z okresu od 1966 do 2016 wykazano, że niechirurgiczne strategie redukcji masy ciała, takie jak interwencja żywieniowa, aktywność fizyczna, leki regulujące metabolizm węglowodanów oraz motywacyjne wywiady byly skuteczne w zwalczaniu otyłości wśród niepłodnych par. Redukcja masy ciała u kobiet w efekcie leczenia dietetycznego oraz zwiększenia aktywności fizycznej była zwiąana $z$ pojawieniem się owulacji, uregulowaniem przebiegu cyklu menstruacyjnego oraz większa szansa na naturalne zajście $\mathrm{w}$ ciązęe. Nie zauważono jednak znaczących efektów redukcji masy ciała w odniesieniu do częstości poronień i skuteczności zapłodnienia in vitro (BEST i współaut. 2017).

\section{PODSUMOWANIE}

Prawidłowy sposób żywienia, warunkujacy optymalna masę ciała oraz zachowanie równowagi oksydo-redukcyjnej wydają się być ważnym elementem mającym wpływ na płodność kobiet i mężczyzn. Pierwszym etapem leczenia niepłodności powinno być poradnictwo dotyczace sposobu żywienia i stylu życia, w tym aktywności fizycznej, spożycia alkoholu, palenia papierosów, narażenia na czynniki środowiskowe oraz na stres.

W swietle istniejacych danych naukowych dieta zbliżona do modelu diety śródziemnomorskiej, czyli bogata w warzywa i owoce, ryby, owoce morza, chude mięso, nabiał o średniej zawartości tłuszczu, zboża, oleje roślinne oraz warzywa strączkowe, orzechy i nasiona, jest potencjalnie najkorzystniejsza dla zachowania prawidłowych funkcji rozrodczych kobiet i mężczyzn. Dieta ta zmniejsza prawdopodobieństwo wystapienia stresu oksydacyjnego i nieprawidłowej (zbyt wysokiej lub zbyt niskiej) masy ciała.

Nadmierna konsumpcja żywności wysokoprzetworzonej, bogatej $\mathrm{w}$ nasycone kwasy tłuszczowe, izomery trans kwasów tłuszczowych, cukry proste oraz niski udział błonnika, co jest charakterystyczne dla diety typu zachodniego, zwiększa ryzyko wystapienia niepłodności i stanowi przeszkodę w jej leczeniu. Należy wspomnieć, iż niezależnie od modelu diety, w każdym przypadku nadmierna podaż energii $z$ diety jest powodem wzrostu masy ciała. Dieta typu zachodniego stanowi większe ryzyko niepłodności, ze względu na wyższe spożycie żywności o wysokiej gęstości energetycznej. Jednak również dieta śródziemnomorska oraz dieta zgodna $z$ zasadami prawidłowego żywienia moga stanowić zagrożenie dla płodności kobiet i mężczyzn, jeśli ich energetyczność będzie przekraczała aktualne zapotrzebowanie organizmu. Składniki mineralne i witaminy powinny być dostarczone przynajmniej w ilościach rekomendowanych przez polskie normy. W każdym przypadku zalecenia żywieniowe powinny być opracowane indywidualnie, na podstawie oceny stanu odżywienia i badań laboratoryjnych. Niedobory składników pokarmowych, o ile nie jest możliwe uzupełnienie ich $z$ dieta, powinny być dostarczone $\mathrm{w}$ postaci zaplanowanej suplementacji.

\section{Streszczenie}

Badania naukowe wskazują, że sposób żywienia w istotny sposób wpływa na płodność kobiet i mężczyzn w wieku rozrodczym. W niniejszym artykule dokonano przeglądu badań naukowych na temat zależności między spożyciem żywności a płodnością. Wykazano, że dieta śródziemnomorska jest optymalnym wzorcem dla diety wspomagającej płodność i leczenie niepłodności. Również dieta określona $\mathrm{w}$ badaniach naukowych jako „prudent pattern" wykazywała korzystne działanie, szczególnie u mężczyzn. $Z$ kolei dieta typu zachodniego wykazywała działanie niekorzystne w zaburzeniach płodności u kobiet i mężczyzn.

\section{LITERATURA}

ACHACHE H., REVEL A., 2006. Endometrial receptivity markers, the journey to successful embryo implantation. Hum. Reprod. Update 12, 731-746.

AgARWAL A., MAKKer K., Sharma R,. 2007. Clinical relevance of oxidative stress in patients with male factory infertility: Evidence-based analysis. AUA Update Ser. 26, 1-12.

Agarwal A., APONTE-MELlado A., PREMkUmar B. J., Shaman A., GuPTA S., 2012. The effect of oxidative stress on female reproduction: a review. Reprod. Biol. Endocrinol. 10, 1-31.

Agarwal A., Mulgund A., Hamada A., Chyatte M. R., 2015. A unique view on male infertility around the Globe. Reprod. Biol. Endocrinol. $26,13-37$.

Attman J. A., TOth T., Furtado J., Campos H., Russ H., ChAVARRO J. E., 2012. Dietary fat and semen quality among men attending a fertility clinic. Hum. Reprod. 27, 1466-1474

Best D., AVEnell A., BHattacharya S., 2017. How effective are weight-loss intervention for improving fertility in woman and men who are overweight or obese? A systematic review and meta-analysis of the evidence. Hum. Reprod. Update 23, 681-705

Braga D., Halpern G., Figueira R. DE C. S., SETTI A. S., IACONELli A., Borges E., 2012. Food intake and social habits in male patients 
and relationship to intracytoplasmic injection outcomes. Feril. Steril. 97, 53-59.

BRoughton D. E, JUNGHEIM E., 2016. A focused look at obesity and the preimplantation trophoblast. Semin. Reprod. Med. 34, 5-10.

BUHLING K., GRAJECKI K., 2013. The effect of micronutrient supplements on female fertility. Curr. Opin. Obstet. Gynecol. 25, 173-180.

Cetin I., Berti C., Calabrese S., 2010. Role of micronutrients in the periconceptional period. Hum. Reprod. Update 16, 80-95.

ChavarRo J. E., Rich-Edwards J. W., Rosner B. A., WilletT W. C., 2007b. Dietary fatty acid intakes and the risk of ovulatory infertility. Am. J. Clin. Nutr. 85, 231-237.

Chavarko J. E., Rich-EDwards J. W., Rosner B. A., WilletT W. C., 2008. Protein intake and ovulatory infertility. Am. J. Obst. Gynecol. 198, 210.e1-210.e7.

CHAVARRO J. E., RICH-EDWARDS J. W., ROSNER B. A., WilletT W. C., 2009. A prospective study of dietary carbohydrate quantity and quality in relation to risk of ovulatory infertility. Eur. J. Clinic. Nutr. 63, 78-86.

Chavarro E. J, TOTH T., Wright D. L., MEEKER J. D., Hauser R., 2010. Body mass index in relation to semen quality, sperm DNA integrity and serum reproductive hormone levels among men attending an infertility clinic. Fertil. Steril. 93, 2222-2231.

Chavarro J. E., Minguez-Alarcon L., Mendiola J., CuTillas-TOlin A., LOPEZ-EsPin J. L., TORRES-CANTERO A., 2014. Trans fatty acid intake is inversely releted to total sperm count in young health men. Hum. Reprod. 29, 429440.

Cichosz G., Czeczot H., 2012. Kwasy tłuszczowe izomerii trans $w$ diecie człowieka. Bromat. Chem. Toksykol. 218, 181-190.

Cutillas-Toĺn A., Manguez-Alarcón L., Mendiola J., LÓPEZ-ESPN J. J., JøRGENSEN N., NAVARRETE-Munoz E. M., TORRES-CANTERo A. M., ChAVARRO J. E., 2015. Mediterranean and western dietary patterns are related to markers of testicular function among healthy men. Hum. Reprod. 30, 2945-2955.

DANIELEWICZ A., PRZYBYŁOWICZ K., PRZYBYŁOWICZ M., 2018. Dietary patterns and poor semen quality risk in men: A cross-sectional study. Nutrients $10,1-13$

Ebisch I. M. W., Thomas C. M. G., Peters W. H. M., BRAat D. D. M., STEEgerS-THEunissen R. P. M., 2007. The importance of folate, zinc and antioxidantsin the pathogenesis and prevention of subfertility. Hum. Reprod. Update $13,163-174$.

ESLAMIN G., AMIRJANNATI N., RASHIDKHANI B., SADEGHI M. R., BAGHESTANI A. R., HEKMATDOOST A., 2016. Adherence to the western pattern is potentially an unfavorable indicator of asthenozoospermia risk: A case-control study. J. Am. Coll. Nutr. 35, 50-58.

Fouladi-Nashta A. A., Gutierrez C. G., Gong J. G., GaRnsworThY P. C., WEBB R., 2007. Impact of dietary fatty acids on oocyte quality and development in lactating dairy cows. Biol. Reprod. 77, 9-17.

GaRcíA-FERnÁNDEZ E., Rico-CABANAS L., ROSGAARD N., ESTRUCH R., BACH-FAIG A., 2014. Mediterranean diet and cardiodiabesity: A review. Nutrients 6, 3474-3500.

Gaskins A. J., COlACI D. S., MENDiOla J., SwAN S. H., ChAVARRo J. E., 2012. Dietary patterns and semen quality in young men. Hum. Reprod. 27, 2899-2907.
GUÉRIN P., El MOUATASSIM S., MÉNÉZO Y., 2001. Oxidative stress and protection against reactive oxygen species in the pre-implantation embryo and its surroundings. Hum. Reprod. Update 7, 175-189.

GuZ J., GackowsKi D., FoKsinsKI M., ROZALSKI R., ZARAKOWSKA E., SIOMEK A., SZPILA A., KOTZBACH M., OLINSKI R., 2013. Comparison of oxidative stress/DNA damage in semen and blood of fertile and infertile men. PLoS One 8, e68490.

HAJDUK M., 2013. Wpływ wybranych składników pokarmowych na funkcjonowanie układu rozrodczego u kobiet. Endokrynol. Otył. Zab. Przem. Mat. 9, 29-33.

HuANG H., MANTON K., 2004. The role of oxidative demage in mitochondria during aging: revive. Front. Biosci. 9, 1100-1117.

JAROSZ M., 2017. Normy żywienia dla populacji Polski. IŻŻ, Warszawa.

Jensen T. K., Heitmann B. L., Blomberg JenSEN M., HALldorsson T. I., ANDERSSON A. M., SKAKKEBAEK N. E., JOENSEN U. N., LAURITSEN M. P., Christiansen P., Dalgård C., Lassen T. H., JøRGENSEN N., 2013. High dietary intake of saturated fat is associated with reduced semen quality among 701 young Danish men from the general population. Am. J. Clin. Nutr. 97,411-8.

JuREWICZ J., RADWAN M., SOBALA W., RADWAN P., BOCHENEK M., HANKE W., 2018. Dietary patterns and their relationship with semen quality. Am. J. Men's Health 12, 575-583.

KAPUSTA F., 2012. Rośliny straczkowe źródłem białka dla ludzi $i$ zwierząt. Nauki Inż. Technol. 1, 16-33.

KARAYIANNIS D., KONTOGINNI M., MENDOROU C., DOUKA L., MASTROMINAS M., YIANNAKOURIS N., 2017. Association between adherence to the Mediterranean diet and semen quality parameters in male partners of couples attempting fertility. Hum. Reprod. 32, 215-222.

KARAYIANNIS D., KONTOGIANNI M. D., MENDOROU C., Mastrominas M., YiannaKouRIS N., 2018. Adherence to the Mediterranean diet and IVF success rate among non-obese women attempting fertility. Hum. Reprod. 33, 494-502.

KAZEMII A., RAMEZANDEH F., NASR-ESFAHANI M. H., 2014. Relationship between dietary fat intake, its major food sources and assisted reproduction parametrs. J. Reprod. Infert. 15, 214221.

Kemal Duru N., Morshedi M., Oehninger S., 2000. Effect of hydrogen peroxide on DNA and plasma membrane integrity of human spermatozoa. Fertil. Steril. 74, 1200-1207.

KHAN M. S., ZAMAN S., SAJJAD M., ShOAIB M., GILANI G., 2011. Assessment of the level of trace element zinc in seminal plasma of male and evaluation of its role in male infertility. Int. J. Appl. Basic Med. Res. 1, 93-96.

KunACHOWICZ H., PRZYGODA B., NADOLNA I., IwANow K., 2017. Tabele składu $i$ wartości odżywczej żywności. PZWL, Warszawa.

KuRZAWA R., KANIEWSKA D., BĄCZKOWSKI T., 2010. Niepłodność jako problem kliniczny $i$ społeczny. Przewod. Lek. 2, 149-150.

LANGLEY S., 2014. A nutrition screening form for female infertility patients. Can. J. Diet. Pract. Res. 75, 195-201.

LIU Y., LUO L., ZHAO H., 2001. Levels of lipid peroxides and superoxide dismutase in peritoneal fluid of patients with endometriosis. J. Tongji. Med. Univ. 21, 166-167.

MAKAR R., TOTH T., 2002. The evaluation of infertility. Am. J. Clinic. Pathol. 117, S95-S103. 
MARTinez P., PREverbio F., CAMEJO I., 2007. Sperm lipid peroxidation and pro-inflammatory cytokines. Asian J. Androl. 9, 102-107.

MCGOWN C., BIRERDINC A., YounOssi Z. M., 2014. Adipose tissue as an endocrine organ. Clin. Liver. Dis. 18, 41-58.

MENDiOla J., TORRES-CANTERO A. M., MORENO-GRAU J. M., TEN J., ROCA M., MORENO-GRAU S., BERNABEU R., 2009. Food intake and its relationship with semen quality: $A$ case-control study. Fertil. Steril. 91, 812-818.

Mendiola J., TORRES-CANTERO A. M., Vioque J., Moreno-Grau J. M., Ten J., Roca M., MoreNO-GRAU S., BERNABEU R., 2010. A low intake of antioxidant nutrients is associated with poor semen quality in patients attending fertility clinics. Fertil. Steril. 93, 1128-1133.

MoJSKA H., 2006. Czy istnieje potrzeba znakowania żywności zawartościa izomerów trans kwasów tłuszczowych? Przem. Spoż. 11, 3841.

Moran L., Norman R., TeEde H. J., 2015. Metabolic risk in PCOS: phenotype and adiposity impact. Trends. Endocrinol. Metab. 26, 136143.

OKA T., 2001. Modulation of gene expression by vitamin B6. Nutr. Res. Rev. 14, 257-266.

PALMER N., BAKOS H., 2012. Impact of obesity on male fertility, sperm function and molecular composition. Spermatogenesis 2, 253-263.

PARK K., Gross M., LEE D. H., HOlvoeT P. Himes J. H., Shikany J. M., Jocobs D. R., 2009. Oxidative stress and insulin resistance: the coronary artery risk development in young adults' study. Diabetes Care 32, 1302-1307.

Petit H. V., Cavalieri G. T. D., Santos G. T. D., MORGAN J., SHARPE P., 2008. Quality of embryos produced from dairy cows fed whole flaxseed and the success of embryo transfer. J. Dairy Sci. 91, 1786-1790.

PIECZYŃSKI J., GRAJETA H., 2014. The role of selenium in human conception and pregnancy. J. Trace Elem. Med. Biol. 29, 31-38.

RACHON D., TEEDE H., 2010. Ovarian function and obesity-interrelationship, impact on women's reproductive lifespan and treatment options. Mol. Cell Endocrinol. 316, 172-179.

RAPORT (Raport Koalicji na rzecz Kompleksowej Terapii Niepłodności), 2015. Wspieramy płodność. Warszawa.

RATAJCZAK M., GieTKA-CZERnel M., 2016. Rola selenu $w$ organizmie człowieka. Post. N. Med. 29, 929-933.

RicCi E., Al-Beitawi S., Cipriani S., Alteri A., CHAFFARINO F., CANDIANI M., GERLI S., VIGANO P., PARAZZINI F., 2018. Dietary habits and semen parameters: A systematic narrative review. Andrology 6, 104-116.

RoBKer R., AKISON L., BRENTON D., BENNETT B. D., Thrupp L. N., Chura L. R., Russell D. L., LANE M., NORMAN R. J., 2009. Obese women exhibit differences in ovarian metabolites, hor mones, and gene expression compared with moderate-weight women. J. Clin. Endocrinol. Metab. 94, 1533-1540.

Rozati R., REDdy P. P., REDdANnA P. P., MuJTABa R., 2002. Role of environmental estrogens in the deterioration of male factor fertility. Fertil. Steril. 78, 1187-1194.

SAFARIENJAD M., 2010. Effect of omega-3 polyunsaturated fatty acid supplementation on semen profile and enzymatic anti-oxidant capacity of seminal plasma in infertile men with idiopathic oligoasthenoteratospermia: A double-blind, placebo-controlled, randomised study. Andrology $43,38-47$.
SAID T., Agrwal A., Sharma R. K., Thomas A. J., 2005. Impact of sperm morphology on DNA damage caused by oxidative stress indiced by beta- nicotinamide adenine dinucleotide phosphate. Fertil. Steril. 83, 95-103.

SAlAZAR J., MARTINEZ M., 2014. C- Reactive protein: clinical and epidemiological perspectives. Cardiol. Res. Pract. 2014, 1-10.

SaleH R., AgRWal A., 2002. Oxidative stress and male infertility: From research bench to clinical practice. J. Androl. 23, 737-752.

SARAVANAN N., HASEeB A., EHTEsham N. Z., GHAFOORUNISSA, 2005. Differential effects of dietary saturated and trans-fatty acids on expression of genes associated with insulin sensitivity in rat adipose tissue. Eur. J. Endocrinol. 153, 159-165.

Scholler E. L., Albanna G., Frolova A. I., Moley K. H., 2012. Insulin rescues impaired spermatogenesis via the hypothalamic-pituitary-gonadal axis in Akita diabetic mice and restores male fertility. Diabetes 61, 1869-1878.

SERDYŃSKA M., PAWELCZYK L., 2008. Epidemiologia niepłodności. [W:] Ginekologia. SŁOMKO Z. (red.). Wyd. Lek., PZWL Warszawa, 465-470.

SHUKLA G., SARIKA M., 2014. Nutritional therapy for male infertility. J. Pharma. Creat. 1, 1116.

SORENSEN T., VIRTUE S., VIDAL-PUIG A., 2010. Obesity as a clinical and public health problem: is there a need for a new definition based on lipotoxicity effects? Biochim. Biophys. Acta. 1801, 400-404.

SZOSTAK-WEGIEREK D., 2011. Sposób żywienia a płodność. Med. Wieku Rozwoj. 15, 431-436.

TOlEDO E., LOPEZ-DEL BURGO C., RUIZ-ZAMBRANA A., DONAZAR M., NAVARRO-BLASCO Í., MARTÍNEZ-GonZÁLEZ M. A., DE IRALA J., 2011. Dietary patterns and difficulty conceiving: a nested case-control study. Fertil. Steril. 96, 1149-1153.

VuJKovic M., De VRIES J. H., DOHLE G. R., BONSEL G. J., Lindemans J., MACKON N. S., VAN DER SPeK P. J., Steegers E. A. P., SteeGERS-THEUNISSEN R. P. M., 2009. Associations between dietary patterns and semen quality in men undergoing IVF/ICSI treatment. Hum. Reprod. 24, 1304-1312.

VujKovic M., DE VRIES J. H., Lindemans J., Macklon N. S., Van Der Spek P. J., SteeGers E. A. P., STEEgers-Theunissen R. P. M., 2010 The preconception Mediterranean dietary pattern in couples undergoing in vitro fertilization/intracytoplasmic sperm injection treatment increases the chance of pregnancy. Fertil. Steril. 94, 2096-2101.

WALCZAK-JEDRZEJOWSKA R., 2015a. Oxidative stress and male infertility. Part I: Factors causing oxidative stress in semen. Post. Andr. $2,5-15$.

WALCZAK-JEDRZEJOWSKA R., 2015b. Oxidative stress and male infertility. Part II. Post. Andr. $2,16-33$.

WHO (World Health Organization), 1980. WHO laboratory manual for the examination of human semen and semen- cervical mucus interaction. Signapore.

WHO (World Health Organization), 2001. Reproductive health indicators for global monitoring: Report of the second interagency meeting, Geneva.

WHO (World Health Organization), 2010. Interna tional statistical classification of diseases and related health problems. Geneva. 
WHO (World Health Organization), 2017. Obesity and overweight fact sheet 2016. Last accessed March 6, 2017.

ZiomkiEwiCZ A., Ellison P., Lipson S. F., Thune

I., JASIENSKA G., 2008. Body fat, energy bal- ance and estradiol levels: a study based on hormonal profiles from complete menstrual cycles. Hum. Reprod. 23, 2555-2563.

KOSMOS Vol. 68, 2, 227-237, 2019

\section{Barbara Sawaniewska, Danuta Gajewska, Ewa Lange}

Department of Dietetic, Faculty of Human Nutrition and Consumer Sciences, Warsaw University of Life Sciences, 159C

Nowoursynowska Str., 02-776 Warszawa,E-mail: barbarasawan@gmail.com

THE INFLUENCE OF NUTRITION ON WOMEN AND MEN FERTILITY

\section{Summary}

The dietary pattern affects fertility in both women and men. This review summarizes current scientific evidence on the relationship between nourishment habits and fertility. The Mediterranean-type diet could be an efficient and healthy alternative enhancing fertility. Similarly, a diet consistent with the principles of proper nutrition defined in scientific studies as a "prudent pattern" also showed beneficial effects, especially among men. Western-type diet showed adverse effects on fertility in women and men.

Key words: diet, fertility, mediterranean diet, western-type diet, oxidative stress, semen quality, body weight 